\title{
The Impact of Network Management on Outcomes in Governance Networks
}

This article is published as: Klijn, E.H, B. Steijn, J. Edelenbos (2010), The impact of network management strategies on the outcomes in governance networks, in Public Administration vol 88, no4: 1063-1082

\author{
Erik-Hans Klijn \\ Bram Steijn \\ Jurian Edelenbos
}

\section{Summary}

There is a vast amount of literature and research on network management strategies. However, only a limited portion of this literature examines the relationship between network management strategies and outcomes (for an exception see Meier and O’Toole 2001) Most of the research focuses on managerial activity or networking rather than on the question of which types of strategies matter the most for outcomes of complex processes in networks. This paper attempts to address the question of whether managerial strategies matter for outcomes and also explores which types of strategies have an effect on outcomes.

The research is based on a survey sent to respondents involved in environmental projects in The Netherlands. The findings show that there is a strong effect of the number of employed network management strategies on perceived outcomes, but a few variations in the effect of four constructed types of network management strategies are found. These include: exploring content, connecting, arranging and process agreements.

\section{Author information}

Professor Dr E.H. Klijn (Professor, Department of Public Administration, Erasmus University Rotterdam and Visiting Professor at the School of Public Policy, University of Birmingham)

Professor Dr B. Steijn (Professor, Department of Public Administration, Erasmus University Rotterdam, The Netherlands)

Dr J. Edelenbos (Associate Professor, Department of Public Administration, Erasmus University Rotterdam, The Netherlands)

Keywords: governance networks, network management, types of management strategies, network outcomes 


\section{Introduction: managing networks}

Today, there is a vast amount of literature on governance networks and the ways in which actors within these networks achieve outcomes. Within this discussion, much attention has recently been paid to the role and importance of network management and network managers. One of the crucial questions being asked is whether network management actually improves cooperation processes within networks and contributes to the outcomes of these networks. There have so far been few studies that attempt to trace the influence of network management in general (for an exception see Meier and O'Toole, 2001; 2007), and almost no studies that explore the effects of separate managerial strategies on outcomes of networks.

\section{The need for managing networks}

The mantra of modern public administration theory is that many decision-making processes take place within complex networks of actors (Hanf and Scharpf, 1978; Kaufman et all, 1986; Marsh and Rhodes, 1992; Kickert et all, 1997; Rhodes, 1997). These networks emerge out of a necessity to interact and are, on the one hand, consciously planned in the sense that actors deliberately interact and attempt to structure these interactions with organisations and rules, but on the other hand, are also unplanned as a result of coincidental interactions and strategies and previously created rules.

Governance networks can roughly be defined as "more or less stable patterns of social relations between mutual dependent actors, which form around policy program and/or cluster of means and which are formed, maintained and changed through series of games” (Koppenjan and Klijn, 2004, pp.69-70) ${ }^{1}$. Crucial to the emergence and existence of networks are dependency relations between actors (Hanf and Scharpf, 1978). The resource dependencies around policy problems or policy programs require actors to interact with one another and create more intensive and enduring interactions (Laumann and Knoke, 1987).

Not surprisingly, there has been a proliferation of literature that has attempted to understand this development theoretically. This type of literature, which can be labelled 
as a network perspective on public policy and management, does not focus so much on the actions of a public actor alone but more on the actions of a network of actors. As such, it attempts to provide a tool for analysing, but also for managing, contemporary governance processes (Scharpf, 1978; Rhodes, 1997; Mandell, 2001; Agranoff and McGuire, 2001). A number of terms have been coined to describe this management activity, including meta governance (Sorenson and Torfing, 2007), network governance and network facilitating, but the most popular terminology that is in use is network management (Agranoff and McGuire, 2001; Gage and Mandell, 1990; Kickert et all, 1997; Mandell, 2001). The basic argument is usually that without adequate network management strategies, it is very difficult, or even impossible, to achieve interesting outcomes in these complex interaction processes.

What this article addresses: the effects of network management

This article investigates the effects of network management strategies on perceived outcomes in governance networks. The research is based on a survey conducted in 20062007 where 337 responses to a questionnaire were received by individuals involved in environmental projects in The Netherlands.

Environmental projects are very suitable for testing assumptions about the relationship between network management strategies and outcomes, because they are good examples of decision-making processes in governance networks. As we will explain in section 3 they deal with wicked problems, many actors are involved with relatively dense interactions and they are sustained over a long period of time (see for characteristics of governance networks: Koppenjan and Klijn, 2004; Sorensen and Torfing, 2007).

The main research question that this article addresses is: What is the effect of network management strategies on perceived outcomes and what strategies seem to matter?

Section 2 deals with basic assumptions about network management. A number of hypotheses for the research are derived based on the previous literature. Section 3 provides an explanation of the research design. Section 4 addresses the question of how network management strategies influence perceived outcomes in governance networks. Section 5 deals with the various types of network management strategies and their 
effects. The article ends with several conclusions.

\section{Network management and network managers: assumptions}

In public administration, we encounter an increasing number of situations where public actors arrange policy making, service delivery or policy implementation within networks of actors (Rhodes, 1997; Sorenson and Torfing, 2007). We use the term 'network' to describe public policy making and implementation through a web of relationships between government, business and civil society actors. Networks are associated with new systems for public policy deliberation, decision and implementation (Pierre and Peters 2000; Koppenjan and Klijn 2004). They are based on interdependencies, but not necessarily equity, between public, private and civil society actors.

As a result of complex interactions which, by definition, characterise networks, it is no simple task to achieve mutually agreeable outcomes. Interactions within the network may produce sharp conflicts about, for instance, the distribution of the costs and benefits of a solution. The different perceptions of the actors involved on, for instance, the nature of the problem(s), the desired solution or the best organisational arrangements to utilize to ensure cooperation, can be major obstacles to achieve meaningful outcomes that satisfy the actors involved. This section looks at the influence of network management on outcomes in governance networks. Network management and outcomes are first defined. This is followed by a discussion of the literature on network management, to find out what has previously been said about its impact on outcomes. Subsequently, different types of network management strategies are highlighted.

\section{Two types of network management}

Since cooperation and the coordination of goals and interests do not occur on their own accord, it is necessary to steer interactions in policy games within networks. The (implicit) assumption in the literature is that a satisfactory outcome is often impossible without network management (Gage and Mandell, 1990; Agranoff and McGuire, 2001; Kickert et all, 1997).

The deliberate attempt to govern processes in networks is called network management (Gage and Mandell, 1990; Kickert et al., 1997; Meier and O‘Toole, 2001). Network 
management aims at initiating and facilitating interaction processes between actors (Friend et al., 1974), creating and changing network arrangements for better coordination (Rogers and Whetten, 1982; Scharpf, 1978) creating new content by exploring new ideas for instance (Koppenjan and Klijn, 2004) and guiding interactions (Gage and Mandell, 1990; Kickert et all., 1997).

Various management strategies have been identified in the literature. In general most of the strategies of network management that have been mentioned can be categorized either as strategies of process management or of institutional design (Gage and Mandell, 1990; Koppenjan and Klijn, 2004). Process management strategies attempt to facilitate interactions between actors in policy games. What is crucial in these types of strategies is that although they are indirect in the sense that they try to facilitate interactions and the actions of other actors, they consider the structure of the network (the rules, positions of actors and resource division) as a given. They are thus direct strategies aimed at actors and interactions (hands-on strategies; see Sorenson and Torfing, 2007).

If management strategies are aimed at altering the institutional characteristics of the network (like changing actor positions, entry rules or other more drastic ways to intervene in the structure of the network), they can be labelled as institutional design strategies (Koppenjan and Klijn, 2004). This article focuses solely on process management strategies.

\section{Outcomes in governance networks}

There has been much discussion in the governance literature on how to measure outcomes of complex decision-making processes in networks. The main conclusion is that measuring these outcomes is a difficult task. One of the reasons for this is that actors have different goals and it is thus difficult to pick a single goal by which to measure outcomes for these processes. Measuring outcomes is also problematic because decisionmaking processes in governance networks are lengthy and the goals of actors are likely to change overtime. Goal displacement is the negative term for this phenomenon while learning is the positive term (see Koppenjan and Klijn, 2004).

Another problem encountered while conducting our research is that it is not possible to assess the 'objective' outcomes (realized dwellings, infrastructure, time of decision- 
making, etc) of the wide variety of projects that were mentioned by the respondents. This problem has been addressed in this paper by using perceived outcomes as a proxy for these outcomes and by using more than one criterion to measure them. This is in keeping with the fact that goals change and that actors have different views about the outcomes. A distinction has been made between content outcomes (the innovative character, cost efficiency, etc) and process outcomes (managerial effort, support of the stakeholders involved). This distinction is also used by other scholars on governance networks where, besides 'hard performance' criteria, a wide variety of other measures are mentioned for evaluation (see, for instance: Skelcher et all, 2005), including measurements that include stakeholder involvement and democratic anchorage (Klijn and Skelcher, 2007; Sorensen and Torfing, 2007).

The content outcomes are characterized by a number of aspects derived from the literature on governance networks and network management. This body of literature mentions many aspects and elements to characterize the substance of results from governance processes. The first element that is used here is the innovative character of outcome. This is the way in which the project showed innovative results (c.f. Nooteboom, 2002). The second element is the integrative aspect of the solution, i.e. the way in which the plan represents different environmental functions (housing, recreation, etc.) (C.f. De Jong and Edelenbos, 2007). The third element is the recognizable contribution made, which refers to the impact of the involvement of the stakeholders in the decision-making process (c.f. Edelenbos and Klijn, 2006). The fourth element is the problem-solving capacity of results. This is the extent to which the solutions really address the problem (c.f. Innes and Boohler, 2003). A fifth element that is identified in the literature is the robustness of the results, i.e. the future robustness (time frame) of the results (c.f. Koppenjan and Klijn, 2004). The sixth element is the relationship between the costs and benefits of results from governance networks. This element ensures that the costs of the plan do not overrun the benefits of a project (c.f. Mantel, 2005).

Process outcomes can also be characterized by a number of different elements that also have been mentioned in the literature on governance networks and network management. The first is the management of the governance network, which refers to the level of satisfaction of the ways in which actors are involved in the project (c.f. Meier and 
O’Toole, 2001). The second element is conflict resolution, i.e. the way in which conflicts have been averted and/or solved (Süsskind and Cruikshank, 1987). The third element identified in the literature is the extent to which the process has encountered stagnations or deadlocks (c.f. Van Eeten, 1999). The fourth element is the productive use of differences in perspectives. This is the way in which differences in frame and perspective have been reconciled (c.f. Koppenjan and Klijn, 2004). The fifth element is contact frequency, i.e. the frequency of interactions between actors (c.f. Meier \& O’Toole, 2001). Finally, the sixth element is the support for results coming from governance networks. This refers to the extent to which stakeholders are satisfied with the results achieved (c.f. Koppenjan and Klijn, 2004).

\section{Network management and outcomes}

The crucial question, of course, is how managerial strategies influence policy decisions and outcomes in governance networks. Although a lot of research on governance networks has been done thus far, this question has not really been addressed until now. Especially studies that use larger data sets (mostly surveys) the so called larger $\mathrm{N}$ studies on this particular question are scarce (but not completely absent; see, for example, Meier and O’Toole, 2001, 2007).

One thing is clear from an observation of the large amount of, and ever growing, literature on networks (both case studies and larger $\mathrm{N}$ studies) - that governance networks are complex and include many different actors. In the introductory chapter of a book that contains case studies from various countries, Torfing (Torfing, 2007) stresses that network actors interact with one another through negotiation and that this results in complex processes. Most of the literature on governance networks, whether case studies (see Mandell, 2001; Agranoff and McGuire, 2003; Agranoff 2007; Marcussen and Torfing, 2007; Bekkers et all, 2007) or larger N studies (see for instance O'Toole et all, 2007; Meier and O’Toole, 2001, 2007), tend to emphasize that it is important to have good contacts with other actors within the network. This network contact and 'embeddedness' are also stressed by various studies that utilize a social network analysis. They show that this embeddedness is important for achieving outcomes (see, for instance, Huang and Provan, 2007; Kenis and Oerlemans, 2008) or achieving innovation (see 
Considine et al, 2008). O'Toole et al (2007) have shown that networking is common among managers both in the US and on the European continent, if the UK, where the sample was taken from, can be taken to be representative of the entire European continent (see also Walker et all, 2007).

There may be differences between networking and employing network management strategies - although the two are related. However, in analyzing the many case studies on governance networks, network management strategies have been shown to play a prominent role in many case studies in the US (Mandell, 2001; Agranoff and McGuire, 2003; Agranoff, 2007; Huang and Provan, 2007), the Scandinavian countries (Jensen and Kahler, 2007; Sorenson, 2007), the UK (Newman, 2001; Sullivan and Skelcher, 2002), the Netherlands (A and D, 2000; B and A, 2006), Italy (Cepiku and Meneguzzo, 2005; Meneguzzo and Cepiku, 2008), Belgium (De Rinck and Voets, 2006), France (see Le Gales, 2001) and Germany (for example: Holtkamp, 2005). Thus, there seems to be a broad consensus about the growing importance of both governance networks and network management as factors in achieving good results.

Network management is necessary most importantly because of the complexity of policy making and service delivery since, in order to achieve interesting results, a wide variety of actors and policy levels have to be connected. As Agranoff and McGuire (2003: 123) conclude in their study on how city officials work with other layers of government and organizations to develop their city economics: "From the perspective of the city government, there is not one cluster of linkages to manage but several clusters- some horizontal some vertical, and some that include both within a context of a single project or program”. This statement is very much in keeping with the scarcity of large $\mathrm{N}$ studies on network management and outcomes of governance networks. Huang and Provan (2007) have shown that network involvement, or network embeddedness, is positively related to social outcomes. Meier and O Toole (2001), in well-known studies on educational districts in Texas, have shown that networking by district managers is positively correlated with the performance of the district.

Thus, both the case studies and the large $\mathrm{N}$ studies tend to highlight the importance of network management. In comparing two cases in Denmark, Sorensen (2007: 107) concludes that: "The case study of the meta-governance of two networks in Skanderborg 
suggests that it is an open question whether or not governance networks can become efficient co-producers of public governance. It depends very much on the ability of public authorities to perform competent meta governance”. Other authors, such as Agranoff and McGuire (2003), Edelenbos and Klijn (2006) and Le Gales (2001), have also stressed the importance of network management activities in the achievement of interesting outcomes. Edelenbos and Klijn (2006: 436) concluded after comparing 6 interactive decision-making cases that: "Our findings on these six case studies do, however, provide a good impression of the importance of good process management for the success of interactive decision-making processes. Management matters in the successful evolution of interactive decision-making processes”.

It should be noted that the case studies identify more specific factors for success compared to the large $\mathrm{N}$ studies, which include political support, the careful use of new policy initiatives, etc. They also stress the importance of national institutional contexts in the observed 'world wide trend to governance'. In analyzing the Oslo Regeneration program in Norway, Hanssen and Klausen (2007: 48) have warned that the Norwegian state "still provides a lot of leeway for the operation of traditional hierarchical government. As consequence, the shift towards governance networks is less obvious in Norway than in other countries”. In addition, Le Gales (2001), in his research in Rennes, has analyzed the development of governance networks in Rennes as a product of elite strategy.

Although these case studies and large $\mathrm{N}$ data studies may have been conducted on different types of policies than those that are studied in this article positive correlations between network management strategies and outcomes in governance networks in environmental projects can be expected. Since most scholars have stressed the importance of networking, embeddedness and network management strategies to the results of complex governance processes, the following hypothesis has been formulated:

Hypothesis 1: If more network management strategies are employed in governance networks around environmental projects, these projects will have better outcomes (both process and content outcomes).

Types of network management strategies and their impact 
The number of management strategies or the strength of the social embeddedness in networks is not the only factor that could explain the effects of governance networks and network management. The type of management strategy used could also explain the outcome of governance networks. Therefore, the various types of network management strategies and their impacts are also of interest. However, most studies on network management do not really distinguish between various types of strategies. There is, therefore, not much material on the impact of various strategies on the outcome of governance networks. In order to fill this void, a typology is first required to ground the research conducted in this paper. Network management can be oriented towards hands on activities in managing interactions between actors within the governance network (A and B, 2008; Sorensen and Torfing, 2007)). The literature has dealt with an impressive number of the types of network management strategies to guide interaction processes, so an exhaustive list cannot be provided here (see Gage and Mandell, 1990; O’Toole, 1988, Agranoff and McGuire, 2001; 2003).

Table 1 provides a summary (albeit a non-exhaustive one) of the types of strategies that have been identified, providing examples of each of the categories.

Table 1 Overview of process management strategies

\begin{tabular}{|c|c|c|c|c|}
\hline $\begin{array}{l}\text { Types of } \\
\text { strategies }\end{array}$ & Process agreements & Exploring content & Arranging & Connecting \\
\hline $\begin{array}{l}\text { Main } \\
\text { strategies } \\
\text { mentioned } \\
\text { in the } \\
\text { literature }\end{array}$ & $\begin{array}{l}\text { Rules for entrance into or } \\
\text { exit from the process, } \\
\text { conflict regulating rules, } \\
\text { rules that specify the } \\
\text { interests of actors or veto } \\
\text { possibilities, rules that } \\
\text { inform actors about the } \\
\text { availability of } \\
\text { information about } \\
\text { decision-making } \\
\text { moments, etc. }\end{array}$ & 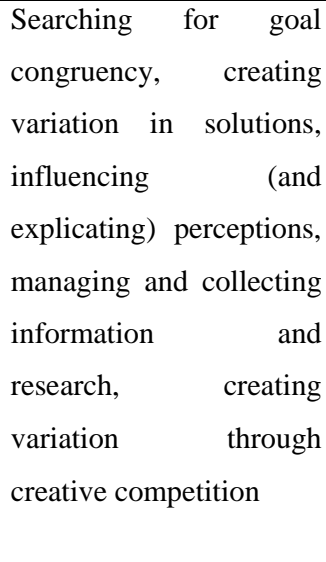 & $\begin{array}{l}\text { Creating new ad } \\
\text { hoc } \\
\text { organisational } \\
\text { arrangements } \\
\text { (boards, project } \\
\text { organisations, } \\
\text { etc.). }\end{array}$ & $\begin{array}{l}\text { Selective (de)activation of } \\
\text { actors, resource mobilizing, } \\
\text { initiating new series of } \\
\text { interactions, } \\
\text { building, coalition } \\
\text { appointment of process } \\
\text { managers, removing obstacles } \\
\text { to co-operation, creating } \\
\text { incentives for co-operation. }\end{array}$ \\
\hline
\end{tabular}

Adapted from Klijn, 2005

Connecting strategies like the activation of actors or resources are required in order to start the game. The network management literature stresses that the network manager has 
to identify the actors required for an initiative and actually create a situation in which they become interested in investing their resources (see also Lynn, 1981). Scharpf (1978) calls this selective activation and states that the correct identification of necessary participants and the lack of opposition from other actors who possess the resources to block the initiative are crucial for inter-organisational policy-making. Sometimes, the manager has to try to deactivate actors because their involvement is not productive. The interactions within the game itself also have to be managed. This can be done by appointing a process manager, who invests time and energy in connecting the actions and strategies of actors to one another during the interactions.

Once the game has begun, strategies for exploring content are necessary to clarify the goals and perceptions of actors (Fisher, 2003, Koppenjan and Klijn, 2004) and to try to invest time and money in developing solutions that create opportunities for actors' participation. However, the process is sometimes short of creative solutions to satisfy the various actors involved. In such cases, more variation is required, for instance by using different teams of experts who compete against one another to create solutions.

The managerial strategy arranging means setting (temporary) structures for consultation, interaction and deliberation, like project organization, communication lines, etc. (Rogers and Whetten, 1982). The transaction costs of these arrangements must be kept as low as possible (Williamson, 1996), but at the same time, the arrangements have to be acceptable to the actors involved.

Another important strategy mentioned in the literature are strategies of process agreements that draft temporary set of rules for interaction that structure the interactions and protect each actor's core values (Koppenjan and Klijn, 2004). The rules can be seen as ground rules for behaviour and interaction in the network that the actors in the network (explicitly) agreed on.

As stated earlier, it is not easy to find evidence in the existing literature on governance networks and network management that provides clues to the relationship of these four types of strategies to content and process outcomes. Given the fact that a substantial portion of the literature emphasizes innovation and learning as important goals of networks (see Huang and Provan, 2007; Agranoff, 2007) and that it is important to search out new information 
and combine actors and their various content and information, one can expect that especially the strategies of exploration and connection will be important. It is also logical to expect there to be a relationship between exploration and connection and content outcomes (for a similar reasoning from a slightly different perspective, see Fisher, 2003). Exploration would be expected to have a more positive relationship with content outcomes than connection, and the connection strategy is probably also positively related to process outcomes. Arranging and process design strategies mainly facilitate interactions. These can be expected to be related to process outcomes and not directly, but perhaps indirectly, to content outcomes.

This line of argumentation leads to the following hypothesis:

Hypothesis 2: with respect to the various managerial strategies, exploring content will be more strongly related to content outcomes while process agreements and arranging will be more strongly related to process outcomes. Connection will be related to both process and content outcomes

\section{Research design: survey on outcomes and management strategies}

The analysis in this article is based on an Internet survey held in 2006-2007 among respondents involved in environmental projects in the Netherlands. The problem with surveying a population like this is that a list of all environmental projects in the Netherlands obviously does not exist - let alone a list of all the respondents involved in these projects and the networks surrounding them. In order to acquire the addresses of people involved in environmental projects, the database of a large knowledge organisation in The Netherlands called 'Habiforum' was therefore utilized. This is a knowledge network in which professionals from the environmental domain participate. It was established in 1999 and incorporates practitioners (from the government, NGOs, water boards, project developers and builders, etc), scientists and consultants (most of who are actually involved in environmental projects).2

These environmental projects that are part of the survey are projects where environmental 
issues are handled, like realising or restructuring build environment (restructuring neighbourhoods, realising new dwellings), water management, business areas, green projects or projects where combinations of these issues are dealt with. More information on the population and survey can be found in the appendix.

\section{Environmental projects as governance networks}

There is also the question of whether these environmental projects match the characteristics of governance networks that have been mentioned in the literature (many actors, frequent interaction between the actors, a certain stability (networks have existed for some time), complex decision-making and wicket issues). As has already been indicated in the introduction, there is much evidence that they can be regarded as governance networks:

- $\quad$ Many actors and frequent contact (see Gage and Mandell, 1990; Agranoff and Mc Guire, 2001; Koppenjan and Klijn, 2004); the average number of actors whom respondents have contact with is 12 . The standard deviation is 4.8 , which is considerably high. This is mainly due to the fact that there are a few respondents with very few contacts. However, 90\% of the respondents do have regular contact with at least 6 or more actors and $70 \%$ with at least 9 or more actors. The frequency of contact is also fairly high.

- $\quad$ Existence and stability over time (Kickert et all, 1997; Agranoff and McGuire, 2003; Meier and O 'Toole, 2001, 2007); the average amount of time taken to complete the project is more than 10 years (see Table 3). Most respondents filled this in as a projection, however, and it is widely known that projects often take longer to complete than estimated. This means that there are enduring networks here;

- $\quad$ Complex issues (Koppenjan and Klijn, 2004; Sorensen and Torfing, 2007); Most of the projects involve various environmental functions (see Table 3) which make the decision-making process complex.

Thus, based on the evidence above, it can be concluded that these environmental projects and governance networks can be appropriately considered in this research. 


\section{Project and respondent characteristics}

The respondents were asked questions about several topics, including trust, project characteristics, management strategies, (perceived) outcomes and the involvement of stakeholders and political parties in the decision-making process. Not all the items in the questionnaire are analyzed in this article as noted above. Each respondent was asked to answer the questions with a specific environmental project in mind.

In terms of the demographics of the respondents and the projects they were involved in, they were predominantly male (83.4\%), middle-aged (on average 48 years old) and highly educated (80.7\% hold a university degree). They had, on average, 12.24 years experience with environmental projects. Their level of involvement in the project can be distinguished as follows:

- $\quad 12.0 \%$ followed the project 'from a distance'

- $\quad 23.4 \%$ were 'thinking along with the project'

- $\quad 35.7 \%$ 'actively participated in the project'

- $\quad 28.8 \%$ were managing the project.

It can thus be seen that the large majority of respondents (almost 65\%) were heavily engaged in the project they answered the questions for. Finally, the background of the respondents (e.g. the parental organization) is also important. There were four different categories of respondents in terms of their background: 1) national civil servants (10.7\%); 2) local civil servants (including civil servants from the counties) (28.5\%); 3) private sector respondents (48.3\%); 4) 'others' (12.4\%). The last group was mostly made up of respondents from stakeholder organizations such as environmental groups.

Table 3 describes characteristics of the projects these respondents were involved in. 
Table 3. Descriptions of project characteristics $(\mathrm{N}=337)$

The project involves

Building of houses

$60.8 \%$

Building of business terrain

Mean number of different activities

(maximum 6)

Median timeline of the project

10 years

Average number of contacts of respondents

Includes: houses, business terrain, water

development, environmental

development and commercial

development

All other organizations - according to

the respondents - with whom the

organization has contact with in the project

Next, the conceptualization and measurement of the main variables included in the analysis to test the hypotheses will be explored. Table 4 provides a brief overview of the measurement of the main variables. A more detailed description can be found in the appendix.

\section{Table 4. Brief descriptions of the measurement of the main variables}

$\begin{array}{ll}\text { Variable } & \text { Nature } \\ \text { Outcomes (divided into content } & \text { Dependent variable } \\ \text { and process outcomes) } & \\ & \\ \text { Project complexity } & \text { Control variable }\end{array}$

Network management strategies Independent variable

\section{Conceptualization and measurement}

Measured by 6 items that were added and divided by 6 to construct two scales ranging from 1 to 5 .

Number of different activities (housing, road development, etc) ranging from 0 to 6 .

16 items measuring managerial activities divided into four subcategories (arranging, process agreements, connecting, exploring content). A summation of the 16 items was used as a measure of the number of strategies. Saved factor scores were used as a value for the four individual strategies (see appendix for more information on this factor analysis). 
Phase of project

Parent organization of

respondent

Number of actors involved
Control variable

Control variable

Control variable
Measured by several types of activities performed in the project.

Organizational background of respondent

Number of actors, indicated by the respondent, who are involved in the project

The analysis will include both a measure of the number of strategies and the four different strategies that have been identified. These variables are clearly correlated (for example, the more types are used, the higher the number of strategies). In fact, a brief analysis shows that the four strategies account for $82 \%$ of the variance in the number of strategies. This means that it does not make much sense to include these variables in one analysis, which is why the testing of Hypotheses 1 and 2 will be conducted in two separate sections ${ }^{3}$.

\section{Network management strategies and their effects}

This section addresses the first hypothesis: If more network management strategies are employed in governance networks around environmental projects, these projects will have better outcomes (both process and content outcomes). The hypothesis is tested using a regression analysis, with the content and process outcomes as dependent variables. The independent variables are the number of strategies employed, with the respondent and project characteristics serving as control variables. 
Table 5 Results of OLS regression analysis with process outcomes as dependent variable $(\mathrm{N}=\mathbf{2 0 8})$

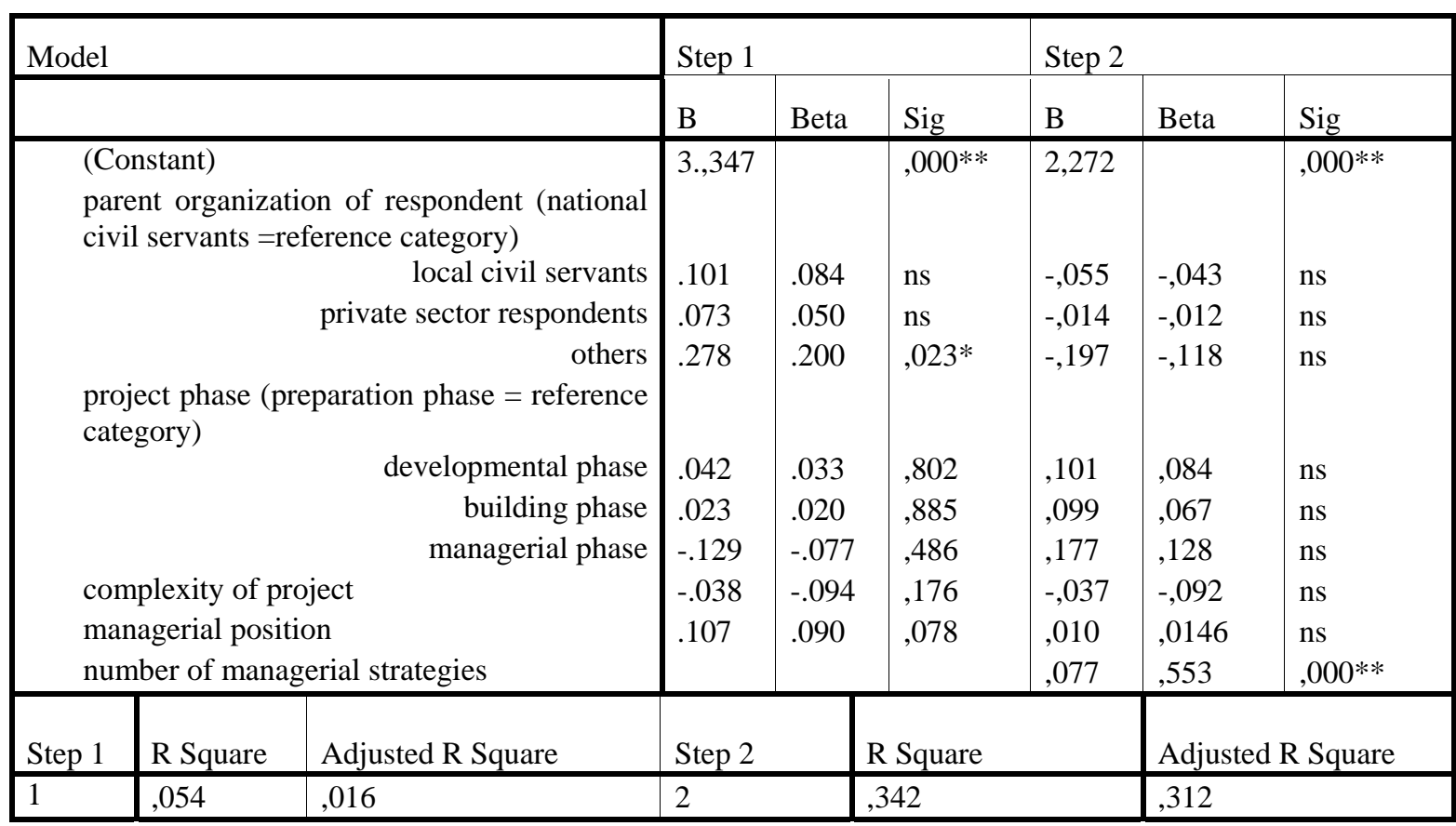

$* \mathrm{p}<0.05^{* *} \mathrm{p}<0.01$

Table 6 Results of OLS regression analysis with content outcomes as dependent variable $(\mathrm{N}=\mathbf{2 1 0})$

\begin{tabular}{|c|c|c|c|c|c|c|c|c|}
\hline \multicolumn{3}{|l|}{ Model } & \multicolumn{3}{|l|}{ Step 1} & \multicolumn{3}{|l|}{ Step 2} \\
\hline & & & B & Beta & Sig & B & Beta & Sig \\
\hline $\begin{array}{ll}1 & (\mathrm{C} \\
\mathrm{pa} \\
\mathrm{ci} \\
\\
\\
\mathrm{pr} \\
\mathrm{ca}\end{array}$ & \multicolumn{2}{|c|}{$\begin{array}{l}\text { (Constant) } \\
\text { parent organization of respondent (national } \\
\text { civil servants =reference category) } \\
\text { local civil servants } \\
\text { private sector respondents } \\
\text { others }\end{array} \begin{array}{l}\text { project phase (preparation phase = reference } \\
\text { category) }\end{array}$} & $\begin{array}{l}3,688 \\
\\
, 115 \\
, 073 \\
-, 039 \\
\\
\\
, 075 \\
-, 103 \\
, 215 \\
, 006 \\
, 175\end{array}$ & $\begin{array}{l}, 086 \\
, 060 \\
-, 022 \\
\\
, 060 \\
-, 066 \\
, 146 \\
, 013 \\
, 140\end{array}$ & $\begin{array}{l}\text { ns } \\
\text { ns } \\
\text { ns } \\
\text { ns } \\
, 047^{*}\end{array}$ & $\begin{array}{l}, 092 \\
-, 049 \\
, 131 \\
, 014 \\
, 088 \\
, 077\end{array}$ & $\begin{array}{l}, 073 \\
-, 031 \\
, 089 \\
, 033 \\
, 071 \\
, 521\end{array}$ & $\begin{array}{l}\text { ns } \\
\text { ns } \\
\text { ns } \\
\text { ns } \\
\text { ns } \\
, 000 * *\end{array}$ \\
\hline Step 1 & R Square & Adjusted R Square & \multicolumn{2}{|l|}{ Step 2} & R Square & \multicolumn{3}{|c|}{ Adjusted R Square } \\
\hline 1 & ,064 & ,027 & 2 & & ,319 & ,289 & & \\
\hline
\end{tabular}

$* \mathrm{p}<0.05 * * \mathrm{p}<0.01$ 
The results in Tables 5 and 6 strongly support the first hypothesis ${ }^{4}$. The effect of the number of managerial strategies on both process and content outcomes is high (beta's are 0.553 and 0.521 respectively). The relative strength of this effect is also shown by the fact that the effect on the dependent variable of the included variables in Step 1 is rather low, but is in both cases substantially higher in Step 2 (from an adjusted explained variance of $1.6 \%$ to $31.2 \%$ for process outcomes, and from $2.7 \%$ to $28.9 \%$ for content outcomes). It should also be noted that in both cases in Step 2, none of the respondents or project characteristics (such as the phase of the project) are statistically significantly related to the perceived outcomes. Overall, the explained variance of the variables that have been included is slightly higher for the process outcomes than for the content outcomes. However, the general message from the analysis is clear: network management strategies are highly relevant to achieve satisfactory outcomes and using more diverse strategies is good for outcomes.

\section{Types of managerial strategies: which has the strongest effect?}

The second hypothesis is then tested: with respect to the various managerial strategies, exploring content will be more strongly related to content outcomes while process agreements and arranging will be more strongly related to process outcomes. Connecting will be related to both process and content outcomes. With this hypothesis, it is not so much the number of strategies, but the types of strategies used that is important. The second hypothesis is also tested through the use of a regression analysis, but instead of the number of strategies employed, the four different strategies derived from the factor analysis (explained in the appendix) are included as independent variables. The results are presented in Tables 7 and 8. 
Table 7 Results of OLS regression analysis with process outcomes as dependent variable $(\mathrm{N}=\mathbf{2 0 8}$

\begin{tabular}{|c|c|c|c|c|c|c|c|c|}
\hline \multicolumn{3}{|l|}{ Model } & \multicolumn{3}{|l|}{ Step 1} & \multicolumn{3}{|l|}{ Step 2} \\
\hline & & & $\mathrm{B}$ & Beta & Sig & $\mathrm{B}$ & Beta & Sig \\
\hline $\begin{array}{l}\mathrm{n} \\
\mathrm{F} \\
\mathrm{F}\end{array}$ & $\begin{array}{l}\text { ct phase } \\
\text { pory) } \\
\text { plexity of p } \\
\text { gerial posi } \\
\text { oration } \\
\text { ecting } \\
\text { nging } \\
\text { ess agreeme }\end{array}$ & $\begin{array}{l}\text { of respondent (national civil } \\
\text { category) } \\
\text { local civil servants } \\
\text { private sector respondents } \\
\text { others } \\
\text { paration phase }=\text { reference } \\
\text { developmental phase } \\
\text { building phase } \\
\text { managerial phase } \\
\text { ct }\end{array}$ & $\begin{array}{l}3,347 \\
\\
, 101 \\
, 073 \\
, 278 \\
\\
, 042 \\
, 023 \\
-, 129 \\
-, 038 \\
, 107\end{array}$ & $\begin{array}{l}\text {,033 } \\
, 020 \\
-, 077 \\
-, 094 \\
, 090\end{array}$ & \begin{tabular}{|l}
, $000^{* *}$ \\
Ns \\
Ns \\
, $023^{*}$
\end{tabular} & $\begin{array}{l}, 070 \\
, 105 \\
, 160 \\
-, 037 \\
-, 031 \\
, 160 \\
, 282 \\
, 106 \\
, 139\end{array}$ & $\begin{array}{l}-, 010 \\
, 010 \\
-, 078 \\
, 059 \\
, 071 \\
, 115 \\
-, 092 \\
-, 026 \\
, 280 \\
, 493 \\
, 183 \\
, 243\end{array}$ & $\begin{array}{l}\text { ns } \\
\text { ns } \\
\text { ns } \\
\text { ns } \\
\text { ns } \\
, 000^{* *} \\
, 000^{* *} \\
, 002^{*} \\
000^{* *}\end{array}$ \\
\hline Step 1 & R Square & Adjusted R Square & Step 2 & & quare & Adj & ed $\mathrm{R}$ & \\
\hline 1 & ,054 & ,016 & 2 & & & 395 & & \\
\hline
\end{tabular}

$* \mathrm{p}<0.05 * * \mathrm{p}<0.01$

Table 8 Results of OLS regression analysis with content outcomes as dependent variable $(\mathrm{N}=210)$

\begin{tabular}{|c|c|c|c|c|c|c|c|c|}
\hline \multicolumn{3}{|l|}{ Model } & \multicolumn{3}{|l|}{ Step 1} & \multicolumn{3}{|l|}{ Step 2} \\
\hline & & & $\mathrm{B}$ & Beta & Sig & $\mathrm{B}$ & Beta & Sig \\
\hline $\begin{array}{l}\mathrm{p} \\
\mathrm{C} \\
\mathrm{C} \\
\mathrm{m} \\
\mathrm{E} \\
\mathrm{C} \\
\mathrm{A} \\
\mathrm{P}\end{array}$ & $\begin{array}{l}\text { ct phase } \\
\text { ory) } \\
\text { plexity of p } \\
\text { gerial posi } \\
\text { oration } \\
\text { ecting } \\
\text { ging } \\
\text { ss agreeme }\end{array}$ & $\begin{array}{l}\text { ff respondent (national civil } \\
\text { ategory) } \\
\text { local civil servants } \\
\text { private sector respondents } \\
\text { Others } \\
\text { aration phase }=\text { reference } \\
\text { developmental phase } \\
\text { building phase } \\
\text { managerial phase } \\
\end{array}$ & $\begin{array}{l}3,688 \\
\\
, 115 \\
, 073 \\
-, 039 \\
\\
, 075 \\
-, 103 \\
, 215 \\
, 006 \\
, 175\end{array}$ & $\begin{array}{l}, 086 \\
, 060 \\
-, 022 \\
\\
\\
, 060 \\
-, 066 \\
, 146 \\
, 013 \\
, 140\end{array}$ & $\begin{array}{l}\text { Ns } \\
\text { Ns } \\
\text { Ns } \\
\text { Ns } \\
, 047^{*}\end{array}$ & $\begin{array}{l}\text {,134 } \\
039 \\
, 192 \\
, 022 \\
, 057 \\
255 \\
, 259 \\
087 \\
, 092\end{array}$ & $\begin{array}{l}, 107 \\
, 025 \\
, 131 \\
051 \\
, 046 \\
, 425 \\
, 428 \\
, 145 \\
, 147\end{array}$ & $\begin{array}{l}\text { ns } \\
\text { ns } \\
\text { ns } \\
\text { ns } \\
\text { ns } \\
, 000^{* *} \\
, 000^{* *} \\
, 011^{*} \\
, 008^{* *}\end{array}$ \\
\hline Step 1 & R Square & Adjusted R Square & \multicolumn{2}{|l|}{ Step 2} & \multicolumn{2}{|l|}{ R Square } & \multicolumn{2}{|c|}{ Adjusted R Square } \\
\hline 1 & ,064 & ,027 & 2 & & ,429 & & ,395 & \\
\hline
\end{tabular}

$* \mathrm{p}<0.05 * * \mathrm{p}<0.01$ 
From Tables 7 and 8, the first part of the hypothesis can be confirmed as exploration is indeed shown to be more strongly correlated to content outcomes. It should also be noted that connecting is strongly related to both process and content outcomes. The second part of the hypothesis, with respect to process outcomes, cannot be confirmed, as the effects of arranging and process agreements on process outcomes are not particularly strong. Although both relationships are significant, especially that between process agreements and process outcomes, the beta is not very high. In fact, the management strategy exploration also has a strong relationship with process outcomes. As can be seen from the analysis, all four strategies are statistically significant in relation to process outcomes. However, from observing the beta effect, it can be seen that the connecting strategy clearly has the strongest effect on process outcomes, followed by content exploration, process agreements and arranging.

\section{Conclusion and discussion}

This article has investigated the relationship between network management and perceived outcomes from governance networks. It has addressed the question whether network management matters and which strategies matter the most. Much case study research has indicated that the answer to this question is yes, but apart from the well-known research studies on Texas educational districts (Meier and O’Toole, 2001, 2007); there is little large $\mathrm{N}$ data on this question. Based on a review of the available literature, a typology of network management strategies (exploring, connecting, arranging and process design) was constructed and two hypotheses were formulated. These hypotheses were tested through a large survey of individuals involved in environmental projects in The Netherlands.

Our research showed that network management is strongly related to outcomes. It can therefore be concluded that network management does, indeed, matter. This also confirms the earlier findings of the case study research and the work of Meier and O’Toole (2001) as well as the work of others that stress networking (Walker et all, 2007) 
and embeddedness (Huang and Provan, 2007) and suggest that these are positively related to outcomes. Thus, the first conclusion from this research is that in general, network management is an important factor in achieving successful outcomes in governance networks.

However, it was also discovered that it does make a difference which network management strategies are employed in facilitation and guiding interaction in the governance network. This is an important finding because although much has been written about network management in general and a large number of specific network management strategies have been identified in the literature, there is very little empirical data about what types of strategies matter the most. A few scholars have mentioned that the outcomes of governance networks depend on the ability or competence of managers (Sorenson, 2007) and the way in which managers strategically operate in complex governance processes (Edelenbos and Klijn, 2007; Agranoff and McGuire, 2007), but an explicit relationship to outcome had not yet been made.

The research conducted in this paper has provided new insights into the relationship between the type of management strategy and (process and content) outcomes. It can be concluded that connecting is the most promising management strategy in realising outcomes. Although the other management strategies did turn out to be statistically significant in realising outcomes, especially the strategy of exploring content, connecting as a strategy turned to be the most effective strategy. It is thus important for a network manager to identify which actors are crucial in the network and then activate and connect these actors in the network. A manager must have connective ability (see also Goldsmith and Eggers, 2004).

Another important finding is that the arranging and process agreements are less important to realize outcome. This is interesting because in at least part of the governance literature and certainly that of one of its manifestations - public private partnerships, a lot of attention is paid to organizational forms (c.f. Benson, 1982). Our findings, however, suggest that network management is far more than solely setting the organizational conditions in place. This is of course slightly discouraging for practitioners who think that they hold the key to success in installing a specific organizational form. However, 
this is in line with much of the case study findings that stress the dynamics of the process and the need to cope with those dynamics through active network management strategies, like connecting and exploring. This issue - that management matters far more than organization - should certainly be explored further.

However, these conclusions must be considered with care for a number of reasons. First, this study has focused on environmental projects. The results cannot automatically be assumed to hold also for other types of projects, such as service delivery. Second, the research has been conducted in The Netherlands, and the cases are all Dutch. Results may differ in other countries with different decision-making cultures. However, the material from Meier and O`Toole does seem to suggest that a number of the conclusions also hold for the US and for other policy fields. Third, the specific context of the project should be taken into account. The connecting strategy could work in certain cases, but in other circumstances the strategy of exploring content, arranging or process agreements could turn out to be more effective. In-depth case study research has to be conducted in order to gain more insight into this. The strong effect of exploring content on both content and process outcomes that came out of this research suggests that managing the content dimension of networks is equally important as managing the process dimension. Since these complex processes are essentially about content and value choices, this may be less surprising than it seems. In the end, actors get involved because they want to achieve certain content and do not simply participate for the sake of the process. 


\section{References}

Agranoff, (2007), Managing within networks; adding value to public organizations, Washigton D.C: Georgetown University Press

Agranoff, R., M. McGuire, (2001), Big questions in public network management research, Journal of Public administration research and Theory, vol 11 (2001), no. 3: 295-326

Agranoff, R. and M. McGuire (2003) Collaborative Public Management; new strategies for local governments, Washington, D.C.: Georgetown University Press.

Bekkers, V., G. Dijkstra, A. Edwards, M. Fenger (2007), Governance and the democratic deficit; assessing the democratic legitimacy of governance practices, Aldershot: Ashgate

Benson, J.K., (1982), A framework for policy analysis, in: Rogers/Whetten(eds.) 1982.

Cepiku, D., M. Meneguzzo (2005), Interorganizational networks in the publivc sector; towards a multidisplinary theoretical framework, International Research seminar of Public Management, Budapest 2005

Considine, M., J.M. Lewis and D. Alexander (2009), Networks, innovations and public policy; politicians, bureaucrats and the pathway to change inside government, Houdmills basigstrole: Palgrave Macmillan

Cropper, S., M. Ebers, C Huxham and P. Ring (2008), The Oxford handbook of inter-organizational relations, Oxford: Oxford University Press

De Rynck, F. \& J. Voets, Democracy in area-based networks: the case of Ghent, in: American Review of Public Administration, 2006, nr. 1, p. 58-78.

J. Edelenbos, E.H. Klijn (2006), Managing stakeholder involvement in decision-making: a comparative analysis of six interactive processes in The Netherlands, Journal of Public Administration Research and Theory vol 16, number 3: 417-446

De Jong, M. \& J. Edelenbos, 2007, An insider's look into policy transfer in trans-national expert networks. in: European Planning Studies, vol.15(5), pp.687-706.

Eeten, M. van, (1999), Dialogues of the Deaf. Defining New Agendas for Environmental Deadlocks, Delft: Eburon

Fischer, F. (2003). Reframing public policy; discursive politics and deliberative practices, Oxford: Oxford University Press.

Gage, R.W., M.P. Mandell (eds.), (1990), Strategies for managing intergovernmental policies and networks, New York/London: Preager

Goldsmith, S. and W.D. Eggers (2004) Governing by Network - The New Shape of the Public Sector, Brookings Institution Press, Washington.

Hanf, K, and F.W. Scharpf (eds.) (1978), Interorganisational Policy Making, London: sage

Hanssen, G.S., J.E. Klaussen (2007), Oslo Inner city district: network failure in the face of policy success in Marcussen and Torfing (2007)pp. 47-65

Holtkamp, L, (2005), Neue formen kommunaler burgerbeteiligung, netwerkeuphorie und beteiligungsrealitat in : J. Oebbecke (2005), Nich normative steuerung in dezeltralen systemen, Stuttgart: Frans Steiner verlag

Huang, K., K.G. Provan (2007), Structural embeddedness and organizational social outcomes in a centrally governed mental health service network, Public Management Rieview, vol 9 nr.2: 169-189

Innes, J.E. and D.E. Booher (2003) Collaborative policymaking: governance through dialogue, in: Hajer, M.A. and H. Wagenaar (eds.) Deliberative policy analysis. Understanding governance in the network society, Cambridge: Cambridge University Press

Jensen, L., H. Kahler (2007), The Danish ministry of finance as metagovner; the case of public sector digitalization, in: Marcussen and Torfing (2007): 174-191

Kaufmann, F.X., G. Majone and V. Ostrom (eds.) (1986) Guidance, Control and Evaluation in the Public Sector: The Bielefeld Interdisciplinary Project, Berlin: Walter de Gruyter.

Kenis, P., L. Oerlemans (2008), The social network perspective: understanding the structure of cooperation in:: Cropper et all (2008): 289-312

Kickert, W.J.M., E.H. Klijn and J.F.M. Koppenjan (eds.) (1997) Managing complex networks; strategies for the public sector, London: Sage.

E.H. Klijn (2005), Networks and inter-organisational management; Challenging steering, evaluation and the role of public actors in public management in E. Ferlie, L. Lynn \& C. Pollitt (eds.) The Oxford Handbook of Public Management, Oxford: Oxford University Press (pp. 257-281 
E.H. Klijn, C.K. Skelcher (2007), Democracy and governance networks: compatible or not? Four conjectures and their implications, Public Administration, vol 85, no 3,2007: 1-22

Koppenjan, J.F.M. and E.H. Klijn, Managing uncertainty in networks, Routledge: Londen

Laumann, E.O., D. Knoke, (1987), The organisational state: Societal choice in National Policy Domains, Wisconsin,WI: University of Wisconsin Press

Le Galès, P. 2001. 'Urban governance and policy networks: on the boundedness of policy networks. A French case.' Public Administration 79, 1, 167-84.

Mandell, M.P. (ed.), 2001, Getting results trough collaboration, Westport: Quorum Books

Mantel, S.J. (2005, second edition). Core concepts of project management. New York: Wiley.

Marcussen, M. \& J. Torfing (red.) (2007). Democratic network governance in Europe, Cheltenham: Edward Elgar.

Marsh, D. (ed.), (1998), Comparing policy networks, Buckingham: Open University Press

Marsh, D., Rhodes, R.A.W. (eds.), (1992), Policy networks in Britisch Government, Oxford: Clarendon Press

Meier, K.J. and L.J. O’Toole (2001) 'Managerial strategies and behaviour in networks: a model with evidence from U.S. public education', in: Journal of Public Administration and Theory (11) 3: 271-293.

Meier, K. L.J. O’Toole (2007), Modelling Public Management: empirical analysis of the managementperformance nexus Public Administration Review, 9(4), 503-527.

Meneguzzo, M., D. Cepiku (eds.) (2008), network pubblici; strategia, strutture e governance, Milano: McGraw-Hill

Milward H. Brinton, K.G. Provan, (2000), Governing the hollow state, Journal of public Administration Research and Theory, vol 10 no. 2 pp. 359-379

Newman, J. (2001), Modernizing governance: new labour, policy and society, London: Sage

Nooteboom, B. (2002). Trust: Forms, foundations, functions, failures and figures. Cheltenhal:Edgar Elgar

O'Toole, L.J. (1988) Strategies for Intergovernmental Management: Implementing Programs in Interorganizational Networks, in: Journal of Public Administration, 11 (4): 417-441.

O’Toole, L.J. (1997), Treating networks seriously: practical and research based agendas in public administration, Public Administration Review, 57: 1 (pp. 43-57)

O’Toole, L.J., R.M. Walker, K. Meier, G. Boyne (2007), Networking in comparative context: Public managers in the USA and the UK, Public Management Review, vol 9, nr.3: 401-420

Pierre, J. and B. Guy Peters. 2000. Governance, Politics and the State. Basingstoke: Macmillan.

Rhodes, R.A.W. (1997), Understanding Government, Open University Press, Buckingham.

Rogers, D.L., D.A. Whetten (eds.), 1982, Interorganizational coordination: theory, research and implementation, Iowa: Iowa State University Press

Scharpf, F.W. (1978) Interorganizational Policy Studies: Issues, Concepts and Perspectives, in: K.I. Hanf and F.W. Scharpf (eds.): 345-370.

Skelcher, C., N. Mathur \& M. Smith (2005). The public governance of collaborative spaces: discourse, design and democracy, Public Administration, 83(3), 573-596.

.Sorenson E., J. Torfing (eds.) (2007), Theories of democratic network governance, Cheltenham: Edward Elgar

Sorensen, E. (2007), Local politicians and administrators as meta governors, in Marcussen and Torfing (2007): 89-108

Sullivan, H. and C. Skelcher. 2002. Working Across Boundaries: Collaboration in Public Services. Basingstoke: Palgrave Macmillan.

Süsskind, L. and J. Cruikshank (1987) Breaking the Impasse. Consensual Approaches to Resolving Public Disputes. London: BasicBooks

Torfing, J. (2007), Introduction: democratic network governance, in: Marcussen and Torfing (eds.) (2007): $1-22$

Walker, R.M., L.J. O’Toole, K. Meier (2007), It's where you are that matters: the networking behaviour of English local government officers, Public Administration vol. 85, nr.2 :739-756

Williamson, O.E., (1996), The mechanisms of governance, Oxford: Oxford University Press 


\section{Appendix: conceptualizing and measuring the variables}

This section provides a more detailed description of the survey and conceptualization and measurement of the variables that are used in our analysis.

\section{Population and survey}

Table 2 describes the population used for the survey, and the number of respondents who have returned a usable questionnaire.

\section{Table 2. Population and Survey}

Number of people on Habiforum List (after 1592

removing researchers)

Returned questionnaires

Analyzed questionnaires

The original list contained 1592 names (after removing university researchers, since the interest was only in practitioners). An e-mail was sent in November 2006, with a (secured) link to a webpage containing the questionnaire. It was known beforehand that this list included many people with only a broad interest in spatial projects and without 'real' involvement in such projects. Therefore, one of the first questions in the questionnaire was about a specific project the respondents were involved in. It was meant to select only those respondents who are really involved in these projects. In total, 547 completed questionnaires were returned. Many of these, however, were incomplete.5 In fact, 188 people did not provide any information about a project they were involved in, and quit the survey after the questions about these projects began to be asked. Many of these respondents indicated in an open question that they were in fact not involved in such a project. These respondents were therefore deleted from the database. Another 22 respondents were also removed, because they were missing on most of the variables. This left 337 respondents who answered most of the questions in the questionnaire and indicated that they themselves were involved in environmental projects.

In relation to the number of e-mails sent, the response rate can be estimated to be $21 \%$, although in relation to the number of people who are involved in environmental projects 
this response can be estimated to be substantially higher. The number of 188 incomplete questionnaires is an indication of the actual population, the following rough estimation of the actual response can be made: Of the 547 returned questionnaires, 188 or $34 \%$ are missing. If this same proportion holds for the total sample, then the actual number of people involved in environmental projects is 1056 (.66*1600). If this assumption is true, the actual size of the response is about 33\% (347/1056). It is possibly even higher, as people not involved in environmental projects will probably not have bothered to take part in the survey

The above implies that care must be taken in interpreting the data, as: a) the actual population of people involved in environmental projects is unknown and b) it is therefore impossible to find out whether the response is representative of this population. However, there is reason to believe that this sample provides a reasonable overview of all environmental projects in the Netherlands (see note 2).

\section{Conceptualizing and measuring outcomes: process and content outcomes}

Table I provides an indication of these two dimensions of outcomes and the (five category Likert) items that were used to measure them.

Table I. Measurements of outcomes

\begin{tabular}{|c|c|}
\hline Content outcomes & Items \\
\hline 1. innovative character & Do you think that innovative ideas are developed during the project \\
\hline 2. integral nature of solution & $\begin{array}{l}\text { Do you think that different environmental functions have been connected } \\
\text { sufficiently? }\end{array}$ \\
\hline $\begin{array}{l}\text { 3. involvement of actors } \\
\text { (content) }\end{array}$ & $\begin{array}{l}\text { Do you think that in general the involved actors have delivered a recognizable } \\
\text { contribution to the development of the results? }\end{array}$ \\
\hline 4. effectiveness solutions & $\begin{array}{l}\text { Do you think that the solutions that have been developed really deal with the } \\
\text { problems at hand? }\end{array}$ \\
\hline 5. effectiveness in the future & Do you think that the developed solutions are durable solutions for the future? \\
\hline 6. Relation costs and benefits & $\begin{array}{l}\text { Do you think that - in general - the benefits exceed the costs of the cooperation } \\
\text { process? }\end{array}$ \\
\hline
\end{tabular}




\section{Process outcomes}

1. level of management

2. conflict resolution

3. deadlocks

4. productive use of differences

5. contact frequency

6. support

\section{Items}

Do you think that the involved actors have contributed substantively to the management of the project?

Do you think that conflicts and differences of opinion have been solved adequately during the project?

Did you witness any disturbing deadlocks during the project?

Do you think that the involved actors have made use of the existing different perspectives and insights (among the actors) in an adequate way with regard to solutions and problems in the project?

Do you think that the involved actors had frequently contact with each other during the project?

Do you think that the results from the project can expect the support of the involved actors?

The Cronbach's alpha of the six items measuring process outcomes is 0.80 , so that they can be considered as forming one scale measuring the perception of process outcomes. The scores on the six items were added up, and divided by six. The items were also recoded, so that a higher score on the scale indicates a more positive perception of the process outcomes. The resulting scale has a mean score of 3.39 and a standard deviation of 0.60 .

The Cronbach's alpha of the six items measuring content outcomes was 0.84. Again, the six items were recoded, added up, and divided by six, resulting in a scale with a mean score of 3.90 and a standard deviation of 0.62 . In both cases, the scores are above the theoretical mean (3), which indicates that the respondents are on average positive about the outcomes. Comparing both means, it also appears that they are somewhat more positive about the content outcomes compared to the process outcomes.

\section{Project complexity}

In the second hypothesis, project complexity figures as a control variable. An environmental project was considered to be more complex when it dealt with more activities. Six different activities were identified: the building of houses, industry development, commercial development, environmental development, road development and water management (compare with Table 2). Based on the responses, we measured for each project whether one or more of these activities were performed. This resulted in a complexity scale ranging from 0 to 6 . According to the mean score, the projects involved 2.98 activities on average, with a broad diversity given a standard deviation of 1.59 . 


\section{Network management strategies}

This is an important variable to test Hypothesis 2. Which network management strategies can be found in governance networks and how effective are they?

As indicated in Section 2, four types of activities were identified based on the available literature:

- arranging; this includes strategies to organize the interactions in governance networks in temporary organizational structures

- $\quad$ exploring content; exploring different views of actors and possible new solutions, and connecting the ideas of different actors

- $\quad$ connecting; securing contacts between actors, improving relations, etc

- $\quad$ process agreements; agreements about process rules and methods of interaction between the actors

Four items were created for each of these strategy types. A factor analysis of these 16 items showed that these 16 items were fairly strongly correlated with one dimension dominating the sultion (for more information please contact the researchers)

\section{Number of strategies employed}

Although the factor analysis confirmed the existence of the four different strategies, it also showed the dominance of the first factor in the solution. As mentioned above, this suggests that good management involves the use of all available strategies. In fact, if a reliability analysis is performed on all sixteen items measuring the network strategies, a Cronbach’s alpha of 0.90 is obtained, indicating a strong correlation between management strategies employed.

To measure the number of strategies employed (an important variable in Hypothesis 1), the sixteen items measuring the strategies were first dichotomized6, and then the number of strategies that were actually used in the project were counted. The resulting variable ranges from 0 (3.6\% of the respondents) to 16 (6.3\%), with a mean of 9.11 strategies used (standard deviation 4.18).

\section{Project and respondent characteristics as control variables}

The above variables measure the main concepts included in the hypotheses. In order to test these, several control variables were also included, with respect to both characteristics of the respondent as well as to relevant project characteristics.

\section{Phase of the project}

The projects the respondents discussed were not all in the same phase. This obviously influences perception on outcomes. For instance, almost by definition there will be fewer outcomes in the first phases of an environmental project. The respondents were not directly asked which phase they were in, but a number of activities were listed (from initiating ideas to implementation of actual maintenance activities) and the 
phase was deduced based on the level of activities respondents indicated they were involved in . Four different phases were discerned: 1) preparation phase (21\%); 2) developmental phase (41\%); 3) building phase (17\%); 4) maintenance phase (21\%).

\section{Parent organization of the respondent}

The respondents come from different backgrounds. As it is possible that this background influences the perception of democratic anchorage and/or the outcome perception, this is controlled for in the analysis. Four different background types can be discerned: 1) national civil servants (11\%); 2) local civil servants (including counties and water board) (29\%); 3) private sector respondents (48\%); 4) 'others’ (13\%). The last group mostly included respondents from stakeholder organizations like environmental groups. In order to incorporate this variable into the analysis, three dummies were included. National civil servants serve as the reference category.

\section{Position in project}

The perception of outcomes can depend on the position of the respondent within the project. Given our interest in the effect of managerial strategies, in the analysis a dummy variable is included distinguishing those with a managerial position (28.8\%) from those without.

\section{Endnotes}

\footnotetext{
${ }^{1}$ We are aware that the term governance is sometimes used in other ways (good governance, corporate governance, governance as new public management). However governance is most often used for situations where governments operate in a multi-actor situation and use horizontal ways of steering/governance (Rhodes, 1997; Pierre, 2000), which fits our description of governance networks. 2 Habiforum has established itself as a fairly important network organization with a lot of members. Looking at the projects mentioned by the respondents, it can be seen that almost all the well-known environmental projects in The Netherlands are represented (and of course a number of lesser known ones as well), which provides confidence that this is a fairly reasonable sample of the available projects in The Netherlands

${ }^{3}$ In fact, it would also not make much sense to include the number of strategies and the results of the factor analysis within one analysis, as these variables are based on the same items, which also explains the high correlation.

${ }^{4}$ As explained above (see note 4), a substantial portion of the respondents were lost because many were not able to answer detailed questions about the projects. To validate the results, the analyses were also performed on the sub-sample of 'more involved respondents' (categories 3 and 4 in Table 2), but the results - not included here - were highly similar.

5 This is a normal situation with internet surveys since a number of people only glance through the questionnaire as they would have done if it was a paper version, and then decide that the survey is not relevant to them, or decide that they do not want to answer it. In this case, the fact that they had to answer the questionnaire for a specific project probably inflated the number of people who only filled in a very limited number of questions
} 
6 The scores 1 and 2 (indicating that the strategy was (certainly) used) were scored as 1, while the other three categories were scored as 0 . 